\title{
Low Environmental Load Process for the Beckmann Rearrangement of Cycloalkanone Oximes by Brønsted Acid Catalyst with Cobalt Salts
}

\author{
Hidetoshi Yamamoto ${ }^{*}$, Masahiro Komeda1, Ayana Ozaki1, Michinori Sumimoto1, \\ Kenji Hori ${ }^{1}$, Tsunemi Sugimoto ${ }^{2}$ \\ ${ }^{1}$ Graduate School of Science and Engineering, Yamaguchi University, Ube, Japan \\ ${ }^{2}$ Ube Laboratory, Ube Industries, Ltd, Ube, Japan \\ Email: ${ }^{*}$-ymmt@yamaguchi-u.ac.jp
}

Received 6 June 2015; accepted 18 August 2015; published 21 August 2015

Copyright (C) 2015 by authors and Scientific Research Publishing Inc.

This work is licensed under the Creative Commons Attribution International License (CC BY). http://creativecommons.org/licenses/by/4.0/

\begin{abstract}
Beckmann rearrangements of oximes to lactams often require harsh conditions and/or the use of large amounts of acid catalyst. To reduce the amount of Brønsted acid required, and to avoid the formation of a large amount of undesirable byproducts under mild reaction conditions, a low environmental load process was developed. Beckmann rearrangements of cyclohexanone oxime and cyclooctanone oxime were achieved using a combination of a Brønsted acid and cobalt tetrafluoroborate hexahydrate. Various Brønsted acid catalysts (10 - $20 \mathrm{~mol} \%$ ) were used to obtain the corresponding lactams in high yields at $80^{\circ} \mathrm{C}$.
\end{abstract}

\section{Keywords}

Beckmann Rearrangement, Cycloalkanone Oximes, Lactam, Cobalt Catalysts, Brønsted Acids

\section{Introduction}

The Beckmann rearrangement is commonly used in organic chemistry to transform ketoximes into amides [1][9]. In particular, cyclohexanone oxime (1) is widely-used to manufacture $\varepsilon$-caprolactam (2) which is used industrially as the raw material for nylon-6. One proposed Beckmann rearrangement method for $\mathbf{1}$ involves an acidcatalyzed reaction. The lactam formed typically forms salts with acids, inactivating the acid catalyst. Thus, an excessive amount of acid is necessary to accomplish the reaction in a practical way. A large excess of base is ${ }^{*}$ Corresponding author.

How to cite this paper: Yamamoto, H., Komeda, M., Ozaki, A., Sumimoto, M., Hori, K. and Sugimoto, T. (2015) Low Environmental Load Process for the Beckmann Rearrangement of Cycloalkanone Oximes by Brønsted Acid Catalyst with Cobalt Salts. International Journal of Organic Chemistry, 5, 147-152. http://dx.doi.org/10.4236/ijoc.2015.53016 
also required for the neutralization and liberation of lactam 2, generating large amounts of byproducts such as ammonium sulfate [10]. Organic catalysts have been developed for sulfate-free Beckmann rearrangements, giving quite satisfactory results in the reaction of acyclic ketoximes and ten- or more-membered ketoximes under mild reaction conditions [11]-[16]. Unfortunately, these catalysts do not give satisfactory results for the reaction of $\mathbf{1}$, and yields of $\mathbf{2}$ are low. One of the best methods for the sulfate-free production of $\mathbf{2}$ is a vapor-phase method using various zeolite catalysts [17], but a disadvantage of this route is that it requires a reaction temperature as high as $350^{\circ} \mathrm{C}$, which causes a massive energy cost and reactor heat deterioration problems. Recently, we developed catalysts combining cobalt salts and Lewis acids which were highly effective for the Beckmann rearrangement of cycloalkanone oximes [18]. In this paper, we focus on the use of more traditional acids, and report that combinations of cobalt salts and Brønsted acids are highly effective for the Beckmann rearrangement of cycloalkanone oximes under mild conditions, assuring more economical and environmentally-friendly process.

\section{Results and Discussion}

Catalytic use of various Brønsted acids is not particularly effective in the Beckmann rearrangement of cyclohexanone oxime (1), as shown in Table 1 . In $\mathrm{MeCN}$ at $80^{\circ} \mathrm{C}$ for $2 \mathrm{~h}$, a $10 \mathrm{~mol} \%$ of benzenesulfonic acid and trifluoro methanesulfonic acid gave $\varepsilon$-caprolactam (2) in a poor yield. Sulfuric acid, one of the most popular strong Brønsted acids, is used in industry for Beckmann rearrangements of $\mathbf{1}$. Even if the acid catalyst is deactivated by the formation of a salt $\left(2 \cdot \mathrm{H}^{+}\right)$with $\mathbf{2}$, the catalyst should give a reasonable amount of $\mathbf{2}$. Nevertheless, sulfuric acid (10 mol\%) does not accelerate the rearrangement reaction, and $\mathbf{2}$ was not detected.

Table 1. Beckmann rearrangement of cyclohexanone oxime (1) using cobalt salts and Brønsted acids ${ }^{\mathrm{a}}$.

\begin{tabular}{|c|c|c|c|c|c|}
\hline \multirow{2}{*}{ Entry } & \multirow{2}{*}{$\begin{array}{l}\text { Brønsted acid } \\
\quad(m o l \%)\end{array}$} & \multirow{2}{*}{ Cobalt salt } & \multirow{2}{*}{ Time/h } & \multicolumn{2}{|c|}{ Yield/\% } \\
\hline & & & & 2 & 1 \\
\hline 1 & $\mathrm{PhSO}_{3} \mathrm{H}(10)$ & - & 2 & 4.9 & 53.1 \\
\hline 2 & $\mathrm{CH}_{3} \mathrm{SO}_{3} \mathrm{H}(10)$ & - & 2 & 0.0 & 47.9 \\
\hline 3 & $\mathrm{CF}_{3} \mathrm{SO}_{3} \mathrm{H}(10)$ & - & 2 & 5.7 & 53.5 \\
\hline 4 & $\mathrm{H}_{3} \mathrm{PO}_{4}(10)$ & - & 2 & 0.0 & 58.8 \\
\hline 5 & $\mathrm{H}_{2} \mathrm{SO}_{4}(10)$ & - & 2 & 0.0 & 56.5 \\
\hline 6 & $\mathrm{H}_{2} \mathrm{SO}_{4}(20)$ & - & 2 & 3.3 & 56.1 \\
\hline 7 & & $\mathrm{CoCl}_{2}$ & 2 & 0.0 & 83.4 \\
\hline 8 & - & $\mathrm{Co}\left(\mathrm{NO}_{3}\right)_{2} \cdot 6 \mathrm{H}_{2} \mathrm{O}$ & 2 & 7.8 & 72.6 \\
\hline 9 & - & $\mathrm{Co}\left(\mathrm{ClO}_{4}\right)_{2} \cdot 6 \mathrm{H}_{2} \mathrm{O}$ & 2 & 8.2 & 40.1 \\
\hline 10 & - & $\mathrm{Co}\left(\mathrm{BF}_{4}\right)_{2} \cdot 6 \mathrm{H}_{2} \mathrm{O}$ & 2 & 10.3 & 32.0 \\
\hline 11 & $\mathrm{PhSO}_{3} \mathrm{H}(10)$ & $\mathrm{CoCl}_{2}$ & 2 & 47.7 & 40.3 \\
\hline 12 & $\mathrm{PhSO}_{3} \mathrm{H}(10)$ & $\mathrm{Co}\left(\mathrm{NO}_{3}\right)_{2} \cdot 6 \mathrm{H}_{2} \mathrm{O}$ & 2 & 22.5 & 29.4 \\
\hline 13 & $\mathrm{PhSO}_{3} \mathrm{H}(10)$ & $\mathrm{Co}\left(\mathrm{ClO}_{4}\right)_{2} \cdot 6 \mathrm{H}_{2} \mathrm{O}$ & 2 & 30.5 & 26.9 \\
\hline 14 & $\mathrm{PhSO}_{3} \mathrm{H}(10)$ & $\mathrm{Co}\left(\mathrm{BF}_{4}\right)_{2} \cdot 6 \mathrm{H}_{2} \mathrm{O}$ & 2 & 64.9 & 26.8 \\
\hline 15 & $\mathrm{PhSO}_{3} \mathrm{H}(10)$ & $\mathrm{Co}\left(\mathrm{BF}_{4}\right)_{2} \cdot 6 \mathrm{H}_{2} \mathrm{O}$ & 4 & 88.3 & 5.5 \\
\hline 16 & $\mathrm{H}_{3} \mathrm{PO}_{4}(10)$ & $\mathrm{Co}\left(\mathrm{BF}_{4}\right)_{2} \cdot 6 \mathrm{H}_{2} \mathrm{O}$ & 2 & 26.8 & 31.6 \\
\hline 17 & $\mathrm{CF}_{3} \mathrm{SO}_{3} \mathrm{H}(10)$ & $\mathrm{Co}\left(\mathrm{BF}_{4}\right)_{2} \cdot 6 \mathrm{H}_{2} \mathrm{O}$ & 2 & 27.9 & 20.0 \\
\hline 18 & $\mathrm{CH}_{3} \mathrm{SO}_{3} \mathrm{H}(10)$ & $\mathrm{Co}\left(\mathrm{BF}_{4}\right)_{2} \cdot 6 \mathrm{H}_{2} \mathrm{O}$ & 2 & 45.0 & 15.2 \\
\hline 19 & $\mathrm{H}_{2} \mathrm{SO}_{4}(10)$ & $\mathrm{Co}\left(\mathrm{BF}_{4}\right)_{2} \cdot 6 \mathrm{H}_{2} \mathrm{O}$ & 2 & 12.5 & 48.3 \\
\hline 20 & $\mathrm{H}_{2} \mathrm{SO}_{4}(20)$ & $\mathrm{Co}\left(\mathrm{BF}_{4}\right)_{2} \cdot 6 \mathrm{H}_{2} \mathrm{O}$ & 2 & 56.7 & 22.5 \\
\hline 21 & $\mathrm{H}_{2} \mathrm{SO}_{4}(10)$ & $\mathrm{Co}\left(\mathrm{BF}_{4}\right)_{2} \cdot 6 \mathrm{H}_{2} \mathrm{O}$ & 24 & 69.3 & 20.2 \\
\hline 22 & $\mathrm{H}_{2} \mathrm{SO}_{4}(20)$ & $\mathrm{Co}\left(\mathrm{BF}_{4}\right)_{2} \cdot 6 \mathrm{H}_{2} \mathrm{O}$ & 24 & 86.3 & 6.6 \\
\hline
\end{tabular}

${ }^{\mathrm{a}} \mathrm{A}$ mixture of cyclohexanone oxime $(0.5 \mathrm{mmol})$, Brønsted acid, and cobalt salt $(10 \mathrm{~mol} \%)$ was stirred in $\mathrm{MeCN}(1.0 \mathrm{~mL})$ at $80^{\circ} \mathrm{C}$. 
While examining catalysts for a sulfate-free Beckmann rearrangement of cyclohexanone oxime (1), it was found that the combination of a variety of cobalt salts and Lewis acids functions efficiently [18]. Cobalt salts block coordination of the oxime to the Lewis acid through the nitrogen atoms, and firmly coordinate with the Lewis acids added in order to promote the rearrangement reaction at the oxygen atoms in the oxime. We therefore decided to focus on the nitrogen blocking ability of cobalt ions to improve the activity of the acid catalyst for the rearrangement reaction by heightening the interaction between the acid catalyst and the oxygen atom of the oxime.

Use of a catalytic amount of a variety of cobalt salts alone is not particularly effective in the Beckmann rearrangement of $\mathbf{1}$. It is surprising that the combined use of benzenesulfonic acid and cobalt chloride provided a notable enhancement in the catalytic activity to give 2 in a $47.7 \%$ yield. Cobalt tetrafluoroborate is the best cocatalyst for the benzenesulfonic acid-catalyzed rearrangement of 1, affording 2 in $64.9 \%$ (2 h) and $88.3 \%$ (4 h) yields. Various Brønsted acids were examined for use as rearrangement catalysts. Unfortunately, the addition of cobalt tetrafluoroborate to $10 \mathrm{~mol} \%$ sulfuric acid gave the same result as when cobalt tetrafluoroborate was used independently. A prolonged reaction time or a slightly increased amount of sulfuric acid was required to obtain 2 in a high yield, and the combination of sulfuric acid (20 mol\%) and cobalt tetrafluoroborate (10 mol\%) gave 2 in a yield as high as $86.3 \%$ by reaction at $80^{\circ} \mathrm{C}$ for $24 \mathrm{~h}$. In Table 2, the effect of reaction time on yield is shown in detail. As would be expected, subsequent reaction increases the yield of 2.

Although cyclooctanone oxime (3) is more reactive than cyclohexanone oxime (1) in Beckmann rearrangement reactions, use of either acatalytic amount of a cobalt salt or a Brønsted acid alone is similarly in effective at the rearrangement of 3, as shown in Table 3. Cobalt tetrafluoroborate is the superior co-catalyst for the trifluoromethanesulfonic acid and sulfuric acid-catalyzed rearrangements of $\mathbf{3}$, as was the case for $\mathbf{1}$ (Scheme $\mathbf{1}$ ). On the other hand, both benzenesulfonic acid and methanesulfonic acid with cobalt perchlorate gave lactam $\mathbf{4}$ in higher yields than with cobalt tetrafluoroborate. The combined use of sulfuric acid (20 mol\%) and cobalt tetrafluoroborate (10 mol\%) gave 4 in a $76.0 \%$ yield by reaction at $80^{\circ} \mathrm{C}$ for $24 \mathrm{~h}$.

It is clearly essential that the strong Brønsted acids used generate salts with the lactams formed and lose their catalytic abilities. Nevertheless, the catalytic amount of acid added continues promoting the Beckmann rearrangement of the oxime to provide the lactam in a high yield. Theoretical calculations confirm that the $N$-protonated cyclohexanone oxime (5) is more stable than the $O$-protonated cyclohexanone oxime (6) and the high energy transition state between $\mathbf{5}$ and $\mathbf{6}$ makes it remarkably difficult to complete the rearrangement (Figure 1) [19]. The aversion to form $O$-protonated oximes makes suppression of the acid-catalyzed Beckmann rearrangement of oximes more likely than salt formation between the acid catalyst and the lactam obtained. A plausible reaction mechanism for the Beckmann rearrangement involves acceleration by the cobalt salt coordinating to the nitrogen atom and the Brønsted acid protonation of the oxygen of the oxime (Figure 2).

\section{Conclusions}

The combination of a variety of cobalt salts with Brønsted acids (acids traditionally used in industrial processes) serves as an efficient catalyst for the Beckmann rearrangement of cycloalkanone oximes to the corresponding

Table 2. Beckmann rearrangement of cyclohexanone oxime (1) using cobalt tetrafluoroborate and sulfuric acids ${ }^{\mathrm{a}}$.

\begin{tabular}{|c|c|c|c|c|c|}
\hline \multirow{2}{*}{ Entry } & \multirow{2}{*}{$\begin{array}{l}\text { Brønsted acid } \\
\text { (mol\%) }\end{array}$} & \multirow{2}{*}{ Cobalt salt } & \multirow{2}{*}{ Time/h } & \multicolumn{2}{|c|}{ Yield/\% } \\
\hline & & & & 2 & 1 \\
\hline 1 & $\mathrm{H}_{2} \mathrm{SO}_{4}(20)$ & $\mathrm{Co}\left(\mathrm{BF}_{4}\right)_{2} \cdot 6 \mathrm{H}_{2} \mathrm{O}$ & 1 & 0.0 & 66.4 \\
\hline 2 & $\mathrm{H}_{2} \mathrm{SO}_{4}(20)$ & $\mathrm{Co}\left(\mathrm{BF}_{4}\right)_{2} \cdot 6 \mathrm{H}_{2} \mathrm{O}$ & 1.5 & 7.6 & 63.0 \\
\hline 3 & $\mathrm{H}_{2} \mathrm{SO}_{4}(20)$ & $\mathrm{Co}\left(\mathrm{BF}_{4}\right)_{2} \cdot 6 \mathrm{H}_{2} \mathrm{O}$ & 2 & 56.7 & 22.5 \\
\hline 4 & $\mathrm{H}_{2} \mathrm{SO}_{4}(20)$ & $\mathrm{Co}\left(\mathrm{BF}_{4}\right)_{2} \cdot 6 \mathrm{H}_{2} \mathrm{O}$ & 6 & 61.2 & 33.8 \\
\hline 5 & $\mathrm{H}_{2} \mathrm{SO}_{4}(20)$ & $\mathrm{Co}\left(\mathrm{BF}_{4}\right)_{2} \cdot 6 \mathrm{H}_{2} \mathrm{O}$ & 12 & 62.9 & 27.4 \\
\hline 6 & $\mathrm{H}_{2} \mathrm{SO}_{4}(20)$ & $\mathrm{Co}\left(\mathrm{BF}_{4}\right)_{2} \cdot 6 \mathrm{H}_{2} \mathrm{O}$ & 18 & 75.7 & 7.3 \\
\hline 7 & $\mathrm{H}_{2} \mathrm{SO}_{4}(20)$ & $\mathrm{Co}\left(\mathrm{BF}_{4}\right)_{2} \cdot 6 \mathrm{H}_{2} \mathrm{O}$ & 24 & 86.3 & 6.6 \\
\hline
\end{tabular}

${ }^{\mathrm{a}} \mathrm{A}$ mixture of cyclohexanone oxime $(0.5 \mathrm{mmol})$, sulfuric acid $(20 \mathrm{~mol} \%)$, and cobalt tetrafluoroborate $(10 \mathrm{~mol} \%)$ was stirred in $\mathrm{MeCN}(1.0 \mathrm{~mL})$ at $80^{\circ} \mathrm{C}$. 
Table 3. Beckmann rearrangement of cyclooctanone oxime (3) using cobalt salts and Brønsted acids ${ }^{\mathrm{a}}$.

\begin{tabular}{|c|c|c|c|c|c|}
\hline \multirow{2}{*}{ Entry } & \multirow{2}{*}{$\begin{array}{l}\text { Brønsted acid } \\
\text { (mol\%) }\end{array}$} & \multirow{2}{*}{ Cobalt salt } & \multirow{2}{*}{ Time/h } & \multicolumn{2}{|c|}{ Yield/\% } \\
\hline & & & & 4 & 3 \\
\hline 1 & $\mathrm{PhSO}_{3} \mathrm{H}(10)$ & - & 2 & 0.7 & 89.4 \\
\hline 2 & $\mathrm{CH}_{3} \mathrm{SO}_{3} \mathrm{H}(10)$ & - & 2 & 0.8 & 87.0 \\
\hline 3 & $\mathrm{CF}_{3} \mathrm{SO}_{3} \mathrm{H}(10)$ & - & 2 & 2.5 & 79.9 \\
\hline 4 & $\mathrm{H}_{3} \mathrm{PO}_{4}(10)$ & - & 2 & 0.0 & 90.5 \\
\hline 5 & $\mathrm{H}_{2} \mathrm{SO}_{4}(10)$ & - & 2 & 1.6 & 86.5 \\
\hline 6 & - & $\mathrm{CoCl}_{2}$ & 2 & 0.0 & 78.9 \\
\hline 7 & - & $\mathrm{Co}\left(\mathrm{NO}_{3}\right)_{2} \cdot 6 \mathrm{H}_{2} \mathrm{O}$ & 2 & 0.0 & 98.0 \\
\hline 8 & - & $\mathrm{Co}\left(\mathrm{ClO}_{4}\right)_{2} \cdot 6 \mathrm{H}_{2} \mathrm{O}$ & 2 & 1.1 & 95.9 \\
\hline 9 & - & $\mathrm{Co}\left(\mathrm{BF}_{4}\right)_{2} \cdot 6 \mathrm{H}_{2} \mathrm{O}$ & 2 & 5.8 & 84.1 \\
\hline 10 & $\mathrm{PhSO}_{3} \mathrm{H}(10)$ & $\mathrm{CoCl}_{2}$ & 2 & 25.0 & 56.7 \\
\hline 11 & $\mathrm{PhSO}_{3} \mathrm{H}(10)$ & $\mathrm{Co}\left(\mathrm{NO}_{3}\right)_{2} \cdot 6 \mathrm{H}_{2} \mathrm{O}$ & 2 & 1.0 & 88.1 \\
\hline 12 & $\mathrm{PhSO}_{3} \mathrm{H}(10)$ & $\mathrm{Co}\left(\mathrm{ClO}_{4}\right)_{2} \cdot 6 \mathrm{H}_{2} \mathrm{O}$ & 2 & 52.5 & 45.8 \\
\hline 13 & $\mathrm{PhSO}_{3} \mathrm{H}(10)$ & $\mathrm{Co}\left(\mathrm{BF}_{4}\right)_{2} \cdot 6 \mathrm{H}_{2} \mathrm{O}$ & 2 & 46.7 & 44.8 \\
\hline 14 & $\mathrm{H}_{3} \mathrm{PO}_{4}(10)$ & $\mathrm{Co}\left(\mathrm{ClO}_{4}\right)_{2} \cdot 6 \mathrm{H}_{2} \mathrm{O}$ & 2 & 2.9 & 88.2 \\
\hline 15 & $\mathrm{H}_{3} \mathrm{PO}_{4}(10)$ & $\mathrm{Co}\left(\mathrm{BF}_{4}\right)_{2} \cdot 6 \mathrm{H}_{2} \mathrm{O}$ & 2 & 2.7 & 58.3 \\
\hline 16 & $\mathrm{CF}_{3} \mathrm{SO}_{3} \mathrm{H}(10)$ & $\mathrm{Co}\left(\mathrm{ClO}_{4}\right)_{2} \cdot 6 \mathrm{H}_{2} \mathrm{O}$ & 2 & 51.5 & 30.1 \\
\hline 17 & $\mathrm{CF}_{3} \mathrm{SO}_{3} \mathrm{H}(10)$ & $\mathrm{Co}\left(\mathrm{BF}_{4}\right)_{2} \cdot 6 \mathrm{H}_{2} \mathrm{O}$ & 2 & 78.7 & 10.8 \\
\hline 18 & $\mathrm{CH}_{3} \mathrm{SO}_{3} \mathrm{H}(10)$ & $\mathrm{Co}\left(\mathrm{ClO}_{4}\right)_{2} \cdot 6 \mathrm{H}_{2} \mathrm{O}$ & 2 & 63.1 & 26.7 \\
\hline 19 & $\mathrm{CH}_{3} \mathrm{SO}_{3} \mathrm{H}(10)$ & $\mathrm{Co}\left(\mathrm{BF}_{4}\right)_{2} \cdot 6 \mathrm{H}_{2} \mathrm{O}$ & 2 & 52.2 & 28.1 \\
\hline 20 & $\mathrm{H}_{2} \mathrm{SO}_{4}(10)$ & $\mathrm{Co}\left(\mathrm{ClO}_{4}\right)_{2} \cdot 6 \mathrm{H}_{2} \mathrm{O}$ & 2 & 18.9 & 64.8 \\
\hline 21 & $\mathrm{H}_{2} \mathrm{SO}_{4}(10)$ & $\mathrm{Co}\left(\mathrm{BF}_{4}\right)_{2} \cdot 6 \mathrm{H}_{2} \mathrm{O}$ & 2 & 32.9 & 61.2 \\
\hline 22 & $\mathrm{H}_{2} \mathrm{SO}_{4}(20)$ & $\mathrm{Co}\left(\mathrm{BF}_{4}\right)_{2} \cdot 6 \mathrm{H}_{2} \mathrm{O}$ & 24 & 76.0 & 19.6 \\
\hline
\end{tabular}

${ }^{\mathrm{a}} \mathrm{A}$ mixture of cyclooctanone oxime $(0.5 \mathrm{mmol})$, Brønsted acid, and cobalt salt $(10 \mathrm{~mol} \%)$ was stirred in $\mathrm{MeCN}(1.0 \mathrm{~mL})$ at $80^{\circ} \mathrm{C}$.

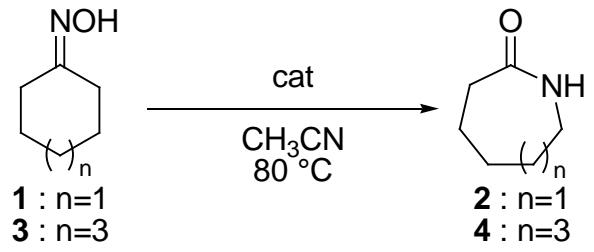

Scheme 1. Beckmann rearrangement of cycloalkanone oximes to lactams.

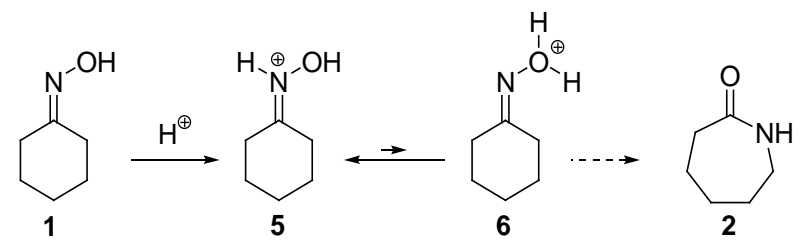

Figure 1. Protonation of cyclohexanone oxime (1). 


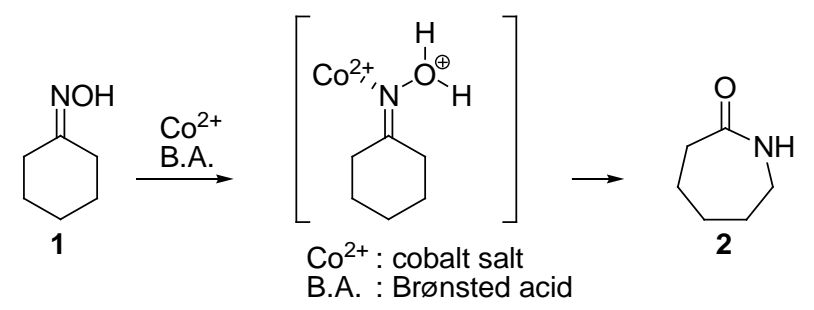

Figure 2. Proposed reaction mechanism.

lactams, which has not been accomplished successfully with organic catalysts due to low reactivity of the oximes. The cobalt salts block $N$-protonation of the oxime, and the Brønsted acids strongly $O$-protonate, promoting the rearrangement. Choosing the correct cobalt salt to generate a more efficient combination catalyst is very important. This new method provides a low environmental load process to lactam formation under mild conditions.

\section{Experimental}

\subsection{General}

All reagents were used as obtained from commercial sources. Acetonitrile (Wako Pure Chemical Industries, Ltd.) was HPLC grade. The cycloalkanone oximes were prepared from the corresponding cycloalkanones and purified by recrystallization. NMR spectra were recorded on a JEOL JNM-GSX500 spectrometer. The NMR studies were carried out using $\mathrm{CDCl}_{3}$ as the solvent and tetramethylsilane as an internal reference.

\subsection{Beckmann Rearrangement}

The general procedure for the Beckmann rearrangement of a cycloalkanone oxime to the corresponding lactam is as follows: A mixture of cycloalkanone oxime $(0.5 \mathrm{mmol})$ and the catalysts in acetonitrile $(1 \mathrm{~mL})$ was stirred at $80^{\circ} \mathrm{C}$ under $\mathrm{N}_{2}$. The mixture was diluted with ethyl acetate $(10 \mathrm{~mL})$, added $\mathrm{NaCl}$-saturated $0.4 \mathrm{~mol} / \mathrm{dm}^{3} \mathrm{NaOH}$ ( $2 \mathrm{~mL}$ for $10 \mathrm{~mol} \%$ acid catalyst), and evaporated under reduced pressure to dryness. The residue was washed with dichloromethane $(50 \mathrm{~mL} \times 2)$, and the mixture was evaporated under reduced pressure. The products were identified by comparison with commercially available chemicals. $\varepsilon$-Caprolactam (2): ${ }^{1} \mathrm{H} \mathrm{NMR}\left(\mathrm{CDCl}_{3}\right) \delta 1.62$ 1.80 (m, 6H), 2.44 - 2.49 (m, 2H), 3.18 - 3.24 (m, 2H), 5.49 (br, 1H). 2-Azacyclononanone (4): ${ }^{1} \mathrm{H}$ NMR $\left(\mathrm{CDCl}_{3}\right)$ $\delta 1.43$ - $1.88(\mathrm{~m}, 10 \mathrm{H}), 2.40-2.46(\mathrm{~m}, 2 \mathrm{H}), 3.33$ - $3.39(\mathrm{~m}, 2 \mathrm{H}), 5.73(\mathrm{br}, 1 \mathrm{H})$.

\section{References}

[1] Gawley, R.E. (2004) The Beckmann Reactions: Rearrangements, Elimination-Additions, Fragmentations, and Rearrangement-Cyclizations. Organic Reactions, 35, 1-420. http://dx.doi.org/10.1002/0471264180.0r035.01

[2] Smith, M.B. and March, J. (2007) March's Advanced Organic Chemistry. 6th Edition, John Wiley \& Sons, Inc., Hoboken, 1613-1616.

[3] Kaur, N., Sharma, P. and Kishore, D. (2012) Application of Different Catalysts in Beckmann Rearrangement. Journal of Chemical and Pharmaceutical Research, 4, 1938-1946.

[4] Zhang, J.S., Riaud, A., Wang, K., Lu, Y.C. and Luo, G.S. (2014) Beckmann Rearrangement of Cyclohexanone Oxime to $\varepsilon$-Caprolactam in a Modified Catalytic System of Trifluoroacetic Acid. Catalysis Letters, 144, 151-157. http://dx.doi.org/10.1007/s10562-013-1114-3

[5] Rancan, E., Aricò, F., Quartarone, G., Ronchin, L., Tundo, P. and Vavasori, A. (2014) Self-Catalyzed Direct Amidation of Ketones: A Sustainable Procedure for Acetaminophen Synthesis. Catalysis Communications, 54, 11-16. http://dx.doi.org/10.1016/j.catcom.2014.05.007

[6] Mao, D., Long, Z., Zhou, Y., Li, J., Wanga, X. and Wang J. (2014) Dual-Sulfonated Dipyridinium Phosphotungstate Catalyst for Liquid-Phase Beckmann Rearrangement of Cyclohexanone Oxime. RSC Advances, 4, 15635-15641. http://dx.doi.org/10.1039/c4ra00552j

[7] Opanasenko, M., Shamzhy, M., Lamač, M. and Čejka, J. (2013) The Effect of Substrate Size in the Beckmann Rearrangement: MOFs vs. Zeolites. Catalysis Today, 204, 94-100. http://dx.doi.org/10.1016/j.cattod.2012.09.008 
[8] Vaschetto, E.G., Monti, G.A., Herrero, E.R., Casuscelli, S.G. and Eimer, G.A. (2013) Influence of the Synthesis Conditions on the Physicochemical Properties and Acidity of Al-MCM-41 as Catalysts for the Cyclohexanone Oxime Rearrangement. Applied Catalysis A General, 453, 391-402. http://dx.doi.org/10.1016/j.apcata.2012.12.016

[9] Zuidhof, N.T., de Croon, M.H.J.M., Schouten, J.C. and Tinge, J.T. (2013) Beckmann Rearrangement of Cyclohexanone Oxime in a Microreactor Setup with Internal Recirculation. Chemical Engineering \& Technology, 36, 13871394. http://dx.doi.org/10.1002/ceat.201300088

[10] Bellussi, G. and Perego, C. (2000) Industrial Catalytic Aspects of the Synthesis of Monomers for Nylon Production. CATTECH, 4, 4-16. http://dx.doi.org/10.1023/A:1011905009608

[11] An, N., Tian, B.-X., Pi, H.-J., Eriksson, L.A. and Deng, W.-P. (2013) Mechanistic Insight into Self-Propagation of Organo-Mediated Beckmann Rearrangement: A Combined Experimental and Computational Study. The Journal of Organic Chemistry, 78, 4297-4302. http://dx.doi.org/10.1021/jo400278c

[12] Maia, A., Albanese, D.C.M. and Landini, D. (2012) Cyanuric Chloride Catalyzed Beckmann Rearrangement of Ketoximes in Biodegradable Ionic Liquids. Tetrahedron, 68, 1947-1950. http://dx.doi.org/10.1016/j.tet.2011.12.051

[13] Hashimoto, M., Obora, Y., Sakaguchi, S. and Ishii, Y. (2008) Beckmann Rearrangement of Ketoximes to Lactams by Triphosphazene Catalyst. The Journal of Organic Chemistry, 73, 2894-2897. http://dx.doi.org/10.1021/jo702277g

[14] Shibamoto, A., Iwahama, T. and Nakano, T. (2008) PCT Int Appl No. 2008078642.

[15] Furuya, Y., Ishihara, K. and Yamamoto, H. (2005) Cyanuric Chloride as a Mild and Active Beckmann Rearrangement Catalyst. Journal of the American Chemical Society, 127, 11240-11241. http://dx.doi.org/10.1021/ja053441x

[16] De Luca, L., Giacomelli, G. and Porcheddu, A. (2002) Beckmann Rearrangement of Oximes under Very Mild Conditions. The Journal of Organic Chemistry, 67, 6272-6274. http://dx.doi.org/10.1021/jo025960d

[17] Kim, J., Park, W. and Ryoo, R. (2011) Surfactant-Directed Zeolite Nanosheets: A High-Performance Catalyst for GasPhase Beckmann Rearrangement. ACS Catalysis, 1, 337-341. http://dx.doi.org/10.1021/cs100160g

[18] Komeda, M., Ozaki, A., Hayashi, K., Sumimoto, M., Hori, K., Sugimoto, T. and Yamamoto, H. (2015) The Effective Catalyst (Cobalt Salt/Lewis Acid) for Beckmann Rearrangement of Cycloalkanone Oximes to Lactams under Mild Conditions. International Journal of Organic Chemistry, 5, 57-62. http://dx.doi.org/10.4236/ijoc.2015.52007

[19] Hori, K., Sumimoto, M. and Yamamoto, H. (2015) Unpublished Data. 